\title{
Singapore plans to double research cash
}

Singapore. The government of Singapore last week announced ambitious plans to double the spending of its National Science and Technology Board (NSTB) to S\$4 billion (US $\$ 2.9$ billion) over the next five years.

The move is expected to sustain the rapid growth in both industrial and government research and development $(R \& D)$ in the island state. But, unlike the preceding fiveyear plan, which focused on industrial research and technology, 30 per cent of the total has been earmarked for long-term strategic research, a move from which Singapore's universities stand to benefit.

NSTB was set up in 1991 under the Ministry of Trade and Industry to promote 'industry-driven' R\&D under a five-year plan aimed at catching up with advanced nations in fields such as electronics, biotechnology, information, materials and manufacturing technology. A total of $\mathbf{\$} \$ 2$ billion was set aside for the five years, of which $\$ \$ 1.1$

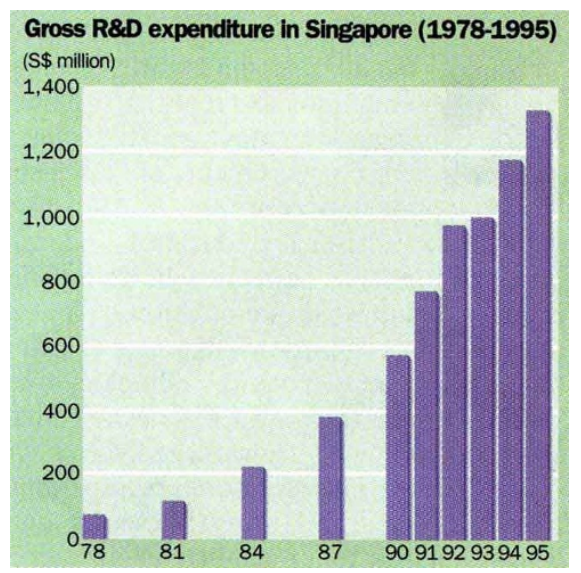

billion has already been spent and the rest is committed, for example, in new buildings and salaries for researchers at new institutes that are in the process of opening.

The money spent on research institutes and centres at the National University of Singapore (NUS) and Nanyang Technological University, has already been substantial. Among them are the Institute of Molecular and Cell Biology (IMCB), the Institute of Microelectronics, the Institute of Molecular Agrobiology and the soon-to-be-established Institute of Materials Research and Engineering, all at NUS.

Investment in the university sector is expected to grow significantly in what is now called the National Science and Technology Plan, rather than just the technology plan. Bernard Tan, dean of science at NUS, says he is "delighted" with the plan. and expects more funds for 'strategic upstream R\&D' in which the universities can participate.

The results of the first five years have been spectacular. Gross expenditure on R\&D by government and industry has leapt from $\$ \$ 572$ million in 1990 to $\$ \$ 1.33$ billion in 1995, almost two-thirds of the latter being contributed by industry. Over the same period, the number of researchers and engineers in Singapore has almost doubled, from 28 to 45 per 10,000 of population, bringing Singapore in line with some advanced European countries.

The government has nevertheless fallen far short of a 1991 target of raising national spending on R\&D to 2 per cent of gross domestic product by 1995 . In fact, this figure has levelled out at about 1.1 per cent since 1992. According to Teo Ming Kian, the chairman of NSTB, announcing the new plan last week, this is partly due to faster than expected growth of the Singapore economy. He pointed out, however, that the government's grants of $\$ \$ 735$ million have brought $\mathrm{S} \$ 2.7$ billion of $\mathrm{R} \& \mathrm{D}$ investments by industry, a multiplier of 3.6.

"We are no longer a low-cost production base," said Yeo Cheow Tong, the minister for trade and industry, at the announcement. "We will increasingly face a 'competition squeeze' from developing countries on the one hand and the developed nations on the other," he said, adding that Singapore had to become an increasingly technologyintensive economy.

One of the biggest problems facing Singapore is a lack of manpower. Local graduates in science and engineering still tend to choose financially rewarding careers in local companies rather than pursue postgraduate research. Most of the rapidly growing population of science and engineering graduate students in Singapore is being recruited overseas, particularly from India and the Chinese mainland (see Nature 383, 13; 1996).

The plan calls for the number of research scientists and engineers to be increased from the present level of nearly 8,000 by 5,000 over the next five years, and 7,000 more in the following five years. To help in this process, 20 "world-class R\&D leaders" will be recruited to act as 'magnets' to attract good local and foreign talent, an approach that has been used with success at several of NUS's new institutes. By 2000, between 12 and 15 new 'top-class' university laboratories will be established at Singapore's two universities.

David Swinbanks

\section{Strategy seeks to make the most of Scottish science}

Edinburgh. The Royal Society of Edinburgh, Scotland's leading scientific organization, has joined forces with Scottish Enterprise, which is backed by the UK government, to launch a long-term strategy designed to encourage the commercial development in Scotland of scientific discoveries made in its universities.

According to officials responsible for the initiative, it is based on an awareness that, despite Scotland's success in attracting foreign-owned manufacturing plants in fields such as microelectronics, its own industry has been slow to capitalize on the scientific output of its 13 universities.

Measured in terms of scientific papers per head of population, Scotland ranks third in the world (after Israel and Sweden), and although it has only 9 per cent of the UK population, it boasts 15 per cent of the UK academic science base. Yet relatively few of its scientific achievements are exploited by Scottish industry.
Drawing on the experience of 'networking' initiatives, both privately and publicly funded, in other countries - particularly the United States - the goal of the initiative is to build a coalition between the academic world, business and finance groups, and the public sector.

"The short-term job impact may not be large," says Crawford Beveridge, the chief executive of Scottish Enterprise. "However, success will help determine the future competitiveness and well-being of the Scottish economy."

In launching the new initiative at HeriotWatt University outside Edinburgh which claims to be the site of Europe's first science park - George Kynoch, the minister for industry at the Scottish Office, said that part of its aim is to complement the Technology Foresight programme introduced by the government in its white paper of May 1993. "Technology Foresight has been about identifying opportunities," said Kynoch. "The strategy that we are launching today is about making sure that the commercial potential of that research is realized."

The initiative, known as Technology Ventures, will be promoted by a high-level 'leadership group' being set up by Scottish Enterprise, and including both industrial and academic members. The Royal Society of Edinburgh has been the joint sponsor of a two-year programme leading to the initiative, and is keen to see it succeed.

"With over 1,000 fellows from all academic disciplines, we can bring to bear a range of scientific expertise," says Tom Johnston, the president of the society and a former vice-chancellor of Heriot-Watt. "This is the first occasion on which Scotland's principal economic development agency and her leading learned society have come together to work on a theme in which both have a major interest and the expertise to pursue it."
David Dickson 